(C) 2022, The Authors. Published by Elsevier Inc. and Fass Inc. on behalf of the American Dairy Science Association ${ }^{\circledR}$. This is an open access article under the CC BY license (http://creativecommons.org/licenses/by/4.0/).

\title{
Management-related factors in dry cows and their associations with colostrum quantity and quality on a large commercial dairy farm
}

\author{
S. Borchardt, ${ }^{*} \odot$ F. Sutter, $\odot$ W. Heuwieser, $\odot$ and P. Venjakob $\odot$ \\ Clinic for Animal Reproduction, Faculty of Veterinary Medicine, Freie Universitaet Berlin, Koenigsweg 65, 14163 Berlin, Germany
}

\begin{abstract}
The objective of this observational study was to evaluate the association of management-related factors in dry cows and colostrum quantity and quality in Holstein cows on a large commercial dairy farm. This study was conducted from January 2018 to December 2020 on a commercial dairy farm in Germany, milking approximately 2,500 Holstein cows. Dairy personnel recorded colostrum quantity $(\mathrm{n}=7,567)$ and evaluated colostrum quality in a subsample of animals $(\mathrm{n}=$ 2,600) using a digital Brix refractometer. Generalized linear mixed models were constructed to evaluate the association of management-related factors and colostrum quantity and quality. Models were run separately for primiparous or multiparous cows. The outcome variable was either colostrum quantity $(\mathrm{kg})$ or quality (\% Brix). Average colostrum quantity was $4.0 \pm 2.5$ $\mathrm{kg}, 5.1 \pm 3.4 \mathrm{~kg}$, and $5.5 \pm 3.5 \mathrm{~kg}$ for cows in lactation 1,2 , and $\geq 3$, respectively. In primiparous cows (n $=2,351)$, colostrum quantity was affected by month of calving (greatest in April $=4.1 \mathrm{~kg}$, and lowest in November $=3.2 \mathrm{~kg}$ ), sex of the calf (female singleton $=3.50 \pm 0.26 \mathrm{~kg}$; male singleton $=3.76 \pm 0.27 \mathrm{~kg}$; twins $=2.97 \pm 0.66 \mathrm{~kg}$ ), stillbirth (stillbirth $=3.14 \pm$ $0.39 \mathrm{~kg}$; no stillbirth $=3.68 \pm 0.31 \mathrm{~kg})$. In multiparous cows $(\mathrm{n}=5,216)$, colostrum quantity was affected by month of calving (greatest in May $=5.5 \mathrm{~kg}$, and lowest in October $=3.8 \mathrm{~kg}$ ), calving ease (calving ease $0=$ $4.23 \pm 0.26 \mathrm{~kg}$; score $1=4.77 \pm 0.21 \mathrm{~kg}$; score $2=$ $4.98 \pm 0.22 \mathrm{~kg} ;$ score $3=5.30 \pm 0.22 \mathrm{~kg}$ ), sex of the calf (female singleton $=4.42 \pm 0.21 \mathrm{~kg}$; male singleton $=5.00 \pm 0.21 \mathrm{~kg} ;$ twins $=5.03 \pm 0.30 \mathrm{~kg}$ ), stillbirth (stillbirth $=4.24 \pm 0.38 \mathrm{~kg} ;$ no stillbirth $=5.39 \pm 0.11$ $\mathrm{kg})$, milk yield in previous lactation $(+0.1 \mathrm{~kg}$ increase for $1,000 \mathrm{~kg}$ more milk yield in previous lactation), days spent in the far-off group $(0.05 \pm 0.003 \mathrm{~kg}$ for every day), and days in the close-up pen $(0.06 \pm 0.010 \mathrm{~kg}$ for
\end{abstract}

Received April 28, 2021.

Accepted October 6, 2021.

*Corresponding author: Stefan.borchardt@fu-berlin.de every day). Average colostrum quality was $25.1 \pm 3.4 \%$ Brix, $24.7 \pm 3.3 \%$ Brix, and $27.6 \pm 4.4 \%$ Brix for cows in lactation 1,2 , and $\geq 3$, respectively. In primiparous cows $(\mathrm{n}=817)$, colostrum quality was affected only by month of calving. Colostrum quality in primiparous cows was greatest in December (26.8\% Brix) and lowest in August (23.9\% Brix). In multiparous cows ( $\mathrm{n}=$ 1,783 ), colostrum quality was affected by parity (lactation $2=25.2 \pm 2.7 \%$ Brix; lactation $3+=27.9 \pm$ $2.7 \%$ Brix), month of calving (greatest in February = $27.5 \%$ Brix, and lowest in August $=25.7 \%$ Brix), milk yield in previous lactation, and colostrum quantity. We observed a seasonal pattern for colostrum quantity and quality. Future intervention studies using multiple farms need to elucidate whether management of the photoperiod or length of exposure to close-up diets, or both, can help to optimize colostrum production.

Key words: close-up diet, colostrum quality, colostrum quantity, dairy cow

\section{INTRODUCTION}

Efficient rearing of replacement heifers is critical for sustainability and overall economic performance of dairy operations. Neonatal diseases such as diarrhea, pneumonia, and navel infections affect economic viability due to costs associated with calf losses, treatments, and long-term negative effects on performance (Heinrichs and Heinrichs, 2011). Diarrhea (56.5\%) and pneumonia $(22.5 \%)$ are responsible for the majority of preweaning calf losses (USDA, 2007). As calves are born with a naïve immune system, adequate passive transfer of immunoglobulins by colostrum intake can be considered as the most critical factor for protection against infectious diseases (Godden et al., 2019). Failure of passive transfer of immunity has been associated with an increased risk for mortality (2.12-fold), pneumonia (1.75-fold), diarrhea (1.51-fold), and overall morbidity (1.91-fold; Raboisson et al., 2016). Apart from colostral IgG transfer, adequate colostrum intake during the first hours of life might have the potential to permanently affect the lifetime performance of a dairy cow (Faber et al., 2005; Soberon et al., 2012). Adequate colostrum in- 
take improved feed efficiency, reduced age at first calving, and might affect milk yield in first lactation (Jones et al., 2004; Faber et al., 2005). It has recently been shown that offering calves a second meal of colostrum $6 \mathrm{~h}$ after the initial feeding soon after birth resulted in improved average daily weight gain and reduced morbidity in preweaning dairy calves and tended to affect first-lactation milk yield (Abuelo et al., 2021). Overall, this highlights the importance of harvesting a sufficient quantity of high-quality colostrum.

Colostrogenesis occurs during the last weeks of gestation (Brandon et al., 1971). Among others, prepartum maternal nutrition (Mann et al., 2016) and nutritional management (Farahani et al., 2017) can affect colostrum production. Prepartum dairy cows have an increased need for energy and protein in response to synthesis of mammary tissue and colostrum as well as requirements for uterine and fetal development (Van Saun and Sniffen, 2014). Estimates from Bell et al. (2000) and NRC (2001) suggest that an additional 120 and 130 $\mathrm{g} / \mathrm{d}$, respectively, of metabolizable protein might be needed to meet AA needs for mammary tissue accretion in prepartum dairy cows. Van Saun and Sniffen (2016) recommended that prepartum diets provide $1,300 \mathrm{~g} / \mathrm{d}$ of MP. Apart from the ration composition, nutritional management, such as length of exposure to prepartum diets, might affect colostrum production. Several studies reported IgG concentration in colostrum to be similar for cows with short dry periods compared with cows with conventional dry periods (Annen et al., 2004; Rastani et al., 2005; Watters et al., 2008; Klusmeyer et al., 2009). Cows with no dry periods, however, had reduced colostrum quality compared with conventional dry periods (Annen et al., 2004; Rastani et al., 2005; Klusmeyer et al., 2009). This indicates that the colostrogenesis period is not sufficient for gamma globulin accumulation in these cows (Collier et al., 2012).

Limited evidence exists regarding the effect of dry period length on colostrum quantity. Typically, the dry period comprises the last $60 \mathrm{~d}$ of gestation, consisting of the first 4 to $6 \mathrm{wk}$, called far-off, and the close-up period, starting around d 255 of gestation (Vieira-Neto et al., 2021). Reducing the dry period from 60 to $40 \mathrm{~d}$ decreased colostrum quantity (8.9 vs. $6.8 \mathrm{~kg}$; Grusenmeyer et al., 2006). Cows with a 60-d dry period had greater colostrum production compared with cows with a 0 -d or 30-d dry period (7.7 vs. 5.3 vs. $5.1 \mathrm{~kg}$; Mayasari et al., 2015). However, only a few studies have examined the optimal length of exposure to prepartum diets and its effect on colostrum production. A longer duration ( 42 d vs. 21 d) of exposure to a close-up diet had no effect on colostrum quantity or quality (Weich et al., 2013; Lopera et al., 2018). A short stay in the close- up pen (10 d vs. $21 \mathrm{~d})$, however, resulted in reduced colostrum quantity (Farahani et al., 2017). It is possible that optimum length of exposure to a prepartum diet differs between nulliparous heifers and parous cows, as nulliparous heifers have an increased demand for MP (Husnain and Santos, 2019).

The objective of this observational study was to evaluate the association of management-related factors in dry cows and colostrum quantity and quality in Holstein cows. We hypothesized that length of exposure to a prepartum diet is associated with colostrum quantity and quality.

\section{MATERIALS AND METHODS}

\section{Animals, Facilities, and Housing}

This observational study was conducted from January 2018 to December 2020 on a commercial dairy farm in Mecklenburg-Vorpommern, Germany, milking approximately 2,500 Holstein cows, with an average annual milk yield of $11,500 \mathrm{~kg} / \mathrm{cow}$. The cows were housed in a naturally ventilated transition management facility from drying off to the first 20 DIM. Cows and heifers were kept separately in sand-bedded freestall pens. Heifer and cow pens had 36 and 144 stalls, respectively, with ad libitum access to feed and water. Heifers were moved to a close-up pen within the transition management facility at d 264 of gestation. Cows were dried off $55 \mathrm{~d}$ before expected parturition and moved to the transition management facility. Around $21 \mathrm{~d}$ before expected calving, cows and heifers were moved to separate close-up pens. Dry cows were fed a TMR diet once daily, consisting of corn silage and grass silage as forage, with corn and canola meal-based concentrate, formulated to meet or exceed the dietary requirements for dry and lactating Holstein cows (NRC, 2001). The ration composition for far-off dry and close-up cows (Table 1) did not vary significantly across time. Feed was pushed up 10 times a day. Prepartum cows and heifers were fed a negative DCAD diet $(-100 \mathrm{mEq} /$ $\mathrm{kg} \mathrm{DM}$ ). Urine $\mathrm{pH}$ was assessed once a week in a subsample of 12 cows in the close-up group. During the study period, the average urine $\mathrm{pH}$ was $5.8( \pm 0.67 ; \mathrm{n}$ $=3,332$ ).

To improve colostrum quality, all prepartum cows were vaccinated during the dry period, and prepartum heifers before calving, against Escherichia coli and bovine rota- and coronavirus (Rotavec Corona, MSD Animal Health, Intervet Deutschland $\mathrm{GmbH}$ ). The vaccination was carried out 3 to 12 wk before calving. Postpartum cows were milked 3 times daily (0600, 1400 , and $2200 \mathrm{~h}$ ). 


\section{Calving Management}

Heifers and cows were moved on a weekly basis to the prepartum pen $21 \mathrm{~d}( \pm 3)$ before expected parturition; there, animals were monitored every $30 \mathrm{~min}$ to detect signs of imminent parturition (i.e., restlessness, vaginal discharge with bloody traces, lying lateral with abdominal contractions, visible or broken amniotic sac, or feet of the emerging calf outside the vulva). When the amniotic sac was visible or broken outside the vulva, or the feet of the emerging calf were observed outside the vulva, the cows were moved into an individual maternity pen $(3.5 \times 3.5 \mathrm{~m})$ bedded with fresh straw. In every animal, a vaginal examination was conducted to assess dilatation of the vulva and cervix, and furthermore position, posture, presentation, and vitality of the calf. If delivery took longer than $1 \mathrm{~h}$ after the appearance of the amniotic sac or calf feet outside the vulva, calving assistance was provided, to reduce calf losses (Schuenemann et al., 2011). Calving assistance was recorded using a 4 -point scale $(0=$ not observed; $1=$ no assistance; $2=$ assistance by 1 person; $3=$ assistance by at least 2 persons). Twins, cesarean sections, and stillbirths were recorded separately.

During vaginal examination, as well as calving assistance, the animals were restrained in headlocks, and the perineum was carefully cleaned with warm water and a 10\% tincture of iodine solution (Braunol, B. Braun Melsungen AG). Before the examination or calving assistance, lubricant (MS Lubricant, MS Schippers $\mathrm{GmbH}$ ) was applied generously to the obstetrical gloves and the cow's vagina.

Calves were separated from their dam immediately after calving and were weighed with an electronic scale (WA200 mobile platform scale, Meier-Brakenberg GmbH \& Co. KG). All newborn calves were placed into a hutch $(1.5 \times 1 \mathrm{~m})$ bedded with fresh straw for the first $24 \mathrm{~h}$ following birth. Navel dipping was performed using a $10 \%$ tincture of iodine solution (Braunol, B. Braun Melsungen AG). Approximately $30 \mathrm{~min}$ after calving, $4 \mathrm{~L}$ of pasteurized (Perfect Udder, Dairy Tech Inc.), pooled, high-quality colostrum $(\geq 22 \%$ Brix; Bielmann et al., 2010) were fed via an esophageal tube feeder (Dairymac Drencher, Dairytop).

\section{Harvest of Colostrum}

Colostrum was harvested immediately after parturition in a separate milking parlor with a self-locking chute. Manual stimulation lasted $30 \mathrm{~s}$ and included pre-dipping, forestripping (removal of 2 streams of colostrum from each teat), and dry wiping using a clean paper towel. The lag time between manual stimulation and attachment of the milk unit clusters was $60 \mathrm{~s}$. The vacuum of the milking equipment (Flo-Star MAX, Boumatic Robotics $\mathrm{GmbH}$ ) was $45 \mathrm{kPa}$, and the milkto-rest ratio was at 60:40. After colostrum harvest, the teats were dipped (Jod 5000, CID Lines N.V.). After each milking, the bucket, including the colostrum, was weighed with a digital hanging scale (digital hanging scale, model No. XY-2003, Etekcity Corporation, minimum weight $200 \mathrm{~g}$ and maximum weight $50 \mathrm{~kg}$ ), and the weight of the bucket $(3.48 \mathrm{~kg})$ was subtracted. A vaginal obstetrical follow-up examination was carried out to identify vaginal injuries or presence of a second calf. Farm personnel assessed colostrum quality for cows that calved in 2020 using a digital Brix refractometer (HI 96801, Hanna Instruments Deutschland GmbH).

\section{Data Collection and Statistical Analyses}

Essential cow data such as cow ID, parity, gestation length, days in the far-off group, days in the prepartum pen, calving ease, stillbirth, date and time of parturition, calf birth weight, sex of calf, twin births, colostrum quantity, colostrum quality, linear somatic cell score at dry off, and 305-d milk yield in the previous lactation were obtained from the on-farm computer software (DairyComp 305, Valley Ag Software) and transmitted

Table 1. Chemical composition (\% unless otherwise noted) of prepartum diets during the experiment from 2018 until 2020

\begin{tabular}{lrrrrrrr}
\hline & \multicolumn{3}{c}{ Far-off } & & \multicolumn{3}{c}{ Close-up } \\
\cline { 2 - 4 } \cline { 6 - 8 } $\begin{array}{l}\text { Nutrient composition } \\
\text { (DM basis) }\end{array}$ & 2018 & 2019 & 2020 & & 2018 & 2019 & 2020 \\
\hline CP & 13.7 & 14.5 & 15.3 & & 14.0 & 14.3 & 14.2 \\
Ether extract & 2.5 & 2.4 & 2.5 & & 2.6 & 2.4 & 2.9 \\
NDF & 51.9 & 53.0 & 52.7 & & 45.7 & 47.8 & 48.8 \\
NFC & 25.1 & 23.1 & 22.5 & & 29.3 & 27.4 & 25.4 \\
Starch & 10.9 & 9.9 & 12.6 & & 16.9 & 14.9 & 15.1 \\
Ash & 6.8 & 7.0 & 7.2 & & 8.7 & 7.7 & 8.9 \\
DCAD ${ }^{2}{ }^{2} \mathrm{mEq} / 100 \mathrm{~g}$ & 16.3 & 6.8 & 6.0 & & -16.5 & -16.9 & -8.5 \\
\hline
\end{tabular}

${ }^{1}$ Calculated as $100-\mathrm{CP}$ - ether extract - NDF - ash.

${ }^{2} \mathrm{DCAD}=[(\mathrm{Na} \%$ of $\mathrm{DM} / 0.023)+(\mathrm{K} \%$ of DM/0.039) $]-[(\mathrm{S} \%$ of $\mathrm{DM} / 0.016)+(\mathrm{Cl} \%$ of DM/0.0355) $]$. 
Table 2. Descriptive statistics for continuous variables from 7,567 Holstein cows enrolled from 1 commercial dairy farm

\begin{tabular}{lcccc}
\hline Variable & Lactation & Mean & SD & Range \\
\hline Age at first calving (mo) & 1 & 22.2 & 1.27 & $19.4-33.4$ \\
Dry period length (d) & 2 & 48.2 & 12.1 & $14-133$ \\
& $3+$ & 54.9 & 19.0 & $17-146$ \\
Days in the far-off pen (d) & 2 & 27.4 & 11.8 & $7-112$ \\
& $3+$ & 34.1 & 18.9 & $7-126$ \\
Days in the close-up pen (d) & 1 & 19.6 & 5.9 & $1-41$ \\
& 2 & 20.8 & 5.4 & $1-37$ \\
Gestation length (d) & $3+$ & 20.8 & 5.6 & $1-42$ \\
& 1 & 274.3 & 4.2 & $257-293$ \\
Previous 305-d milk yield (kg) & 2 & 276.2 & 4.4 & $257-290$ \\
Colostrum quantity (kg) & $3+$ & 277.0 & 4.7 & $257-290$ \\
& 2 & 12,922 & 1,934 & $4,190-20,020$ \\
Colostrum quality ${ }^{1}$ (\% Brix) & 1 & 13,022 & 2,184 & $1,390-21,270$ \\
& 2 & 4.0 & 2.5 & $0.5-17.0$ \\
& $3+$ & 5.1 & 3.4 & $0.5-19.5$ \\
& 1 & 5.5 & 3.5 & $0.5-20.0$ \\
& 2 & 25.1 & 3.4 & $16.5-39.0$ \\
Colost & $3+$ & 24.7 & 3.3 & $15.0-36.0$ \\
& & 27.6 & 4.4 & $10.5-46.5$ \\
\hline
\end{tabular}

${ }^{1}$ Colostrum quality was assessed using a digital Brix refractometer for all cows calved in 2020 (lactation $1, \mathrm{n}$ $=817$; lactation $\geq 2, \mathrm{n}=1,783$ ).

to Microsoft Excel (Office 2013, Microsoft Deutschland Ltd.).

Gestation length has been associated with health and productive and reproductive performance in dairy cows (Vieira-Neto et al., 2021). Cows with a gestation length shorter or longer than 3 standard deviations from the mean were removed as previously described (VieiraNeto et al., 2021). Therefore, cows with a gestation length shorter than $257 \mathrm{~d}(\mathrm{n}=90)$ or longer than 293 $\mathrm{d}(\mathrm{n}=13)$ and cows that spent $0 \mathrm{~d}$ in the close-up pen $(\mathrm{n}=181)$ were removed from the database. Gestation length was categorized as short (range between 257 and 269 d), normal (270-280 d), or long (281-293 d).

Statistical analyses were performed using SPSS for Windows (version 22.0, IBM Corp.). Four separate generalized linear mixed models were constructed using the GENLINMIXED procedure of SPSS to evaluate the association of management-related factors and colostrum quantity and quality for primiparous or multiparous cows. The outcome variable was either colostrum quantity $(\mathrm{kg})$ or quality (\% Brix). Cow was the experimental unit. According to the model-building strategies described by Dohoo et al. (2009), each parameter considered for the mixed model was separately analyzed in a univariable model, including the parameter as a fixed factor (i.e., categorical parameter) or covariate (i.e., continuous parameter). Only parameters resulting in univariable models with $P \leq 0.20$ were included in the final mixed model. Selection of the model that best fit the data was performed by testing each effect separately in a multivariable model and finding the model with the lowest value for the Akaike information criterion, using a backward elimination procedure that removed all variables with $P>0.10$ from the model. Regardless of the significance level, days in the far-off

Table 3. Descriptive statistics for categorical variables (\%) from 7,567 Holstein cows enrolled from 1 commercial dairy farm

\begin{tabular}{|c|c|c|}
\hline \multirow[b]{2}{*}{ Variable } & \multicolumn{2}{|c|}{ Parity } \\
\hline & Primiparous & Multiparous \\
\hline \multicolumn{3}{|l|}{ Calving ease $^{1}$} \\
\hline 0 & 2.6 & 7.6 \\
\hline 1 & 53.8 & 59.1 \\
\hline 2 & 18.4 & 15.3 \\
\hline 3 & 25.2 & 18.0 \\
\hline \multicolumn{3}{|l|}{ Stillbirth } \\
\hline Alive & 95.8 & 98.6 \\
\hline Dead on arrival & 4.2 & 1.4 \\
\hline \multicolumn{3}{|l|}{ Sex of calf } \\
\hline Male singleton & 31.5 & 48.8 \\
\hline Female singleton & 67.8 & 48.1 \\
\hline Twins & 0.7 & 3.1 \\
\hline \multicolumn{3}{|l|}{ Month of calving } \\
\hline January & 6.0 & 7.4 \\
\hline February & 7.2 & 6.5 \\
\hline March & 7.3 & 6.7 \\
\hline April & 8.9 & 6.8 \\
\hline May & 8.8 & 7.0 \\
\hline June & 10.0 & 8.4 \\
\hline July & 8.5 & 7.9 \\
\hline August & 7.0 & 10.9 \\
\hline September & 10.9 & 9.8 \\
\hline October & 8.2 & 8.8 \\
\hline November & 8.3 & 9.2 \\
\hline December & 9.0 & 10.3 \\
\hline
\end{tabular}

${ }^{1}$ Calving assistance was recorded using a 4 -point scale $(0=$ not observed; $1=$ no assistance; $2=$ assistance by 1 person; $3=$ assistance by at least 2 persons). 
dry cow pen and close-up pen, as well as gestation length, were forced to remain in the model.

For primiparous cows, the initial model for colostrum quantity contained the following explanatory variables as fixed effects: age at first calving (continuous), month of calving (1-12), calving ease (score $0-3$ ), calving day of the week (Monday-Sunday), stillbirth (alive vs. dead on arrival), sex of the calf (male singleton vs. female singleton vs. twins), gestation length (short vs. normal vs. long), and days in the close-up pen (DINCU; continuous).

For multiparous cows, the initial model for colostrum quantity contained the following explanatory variables as fixed effects: parity ( 2 vs. $\geq 3$ ), month of calving (1-12), calving ease (score 0-3), calving day of the week (Monday-Sunday), stillbirth (alive vs. dead on arrival), sex of the calf (male singleton vs. female singleton vs. twins), gestation length (short vs. normal vs. long), milk yield in previous lactation (continuous), linear somatic cell score at dry off (continuous), days in the far-off group (continuous), and DINCU (continuous).

The initial model for colostrum quality contained the same explanatory variables as for colostrum quantity. Additionally, colostrum quantity (continuous) was included. We tested all biologically plausible 2-way interactions.

Figures were created with predicted responses for each cow contributing data for the statistical analysis of the specific dependent variable analyzed. The predicted values were obtained from the final models using fitted values with best linear unbiased estimates.

\section{RESULTS}

From January 1, 2018, through December 31, 2020, a total of 8,709 cows calved. After exclusion of 1,145 animals $(13.1 \%)$ because of incomplete data sets, 7,567 animals were available for final statistical analyses. Of those 2,351 (31.1\%), 1,958 (25.9\%), and 3,258 (43.0\%) were in lactation 1,2 , and $\geq 3$, respectively. Descriptive statistics of cows used in the statistical analysis in this study are presented in Tables 2 and 3, considering parity. Average dry period length was $48.2 \mathrm{~d}$ and 54.9 $\mathrm{d}$ for cows in lactation 2 and $\geq 3$, respectively. Average days spent in the close-up pen was $19.6 \mathrm{~d}, 20.8 \mathrm{~d}$, and $20.8 \mathrm{~d}$ for cows in lactation 1,2 , and $\geq 3$, respectively. A histogram of exposure to a prepartum diet stratified by parity is presented in Figure 1 .

\section{Colostrum Quantity}

Average colostrum quantity was $4.0 \mathrm{~kg}, 5.1 \mathrm{~kg}$, and $5.5 \mathrm{~kg}$ for cows in lactation 1,2 , and $\geq 3$, respectively. A histogram of colostrum quantity is presented in Figure 2 .

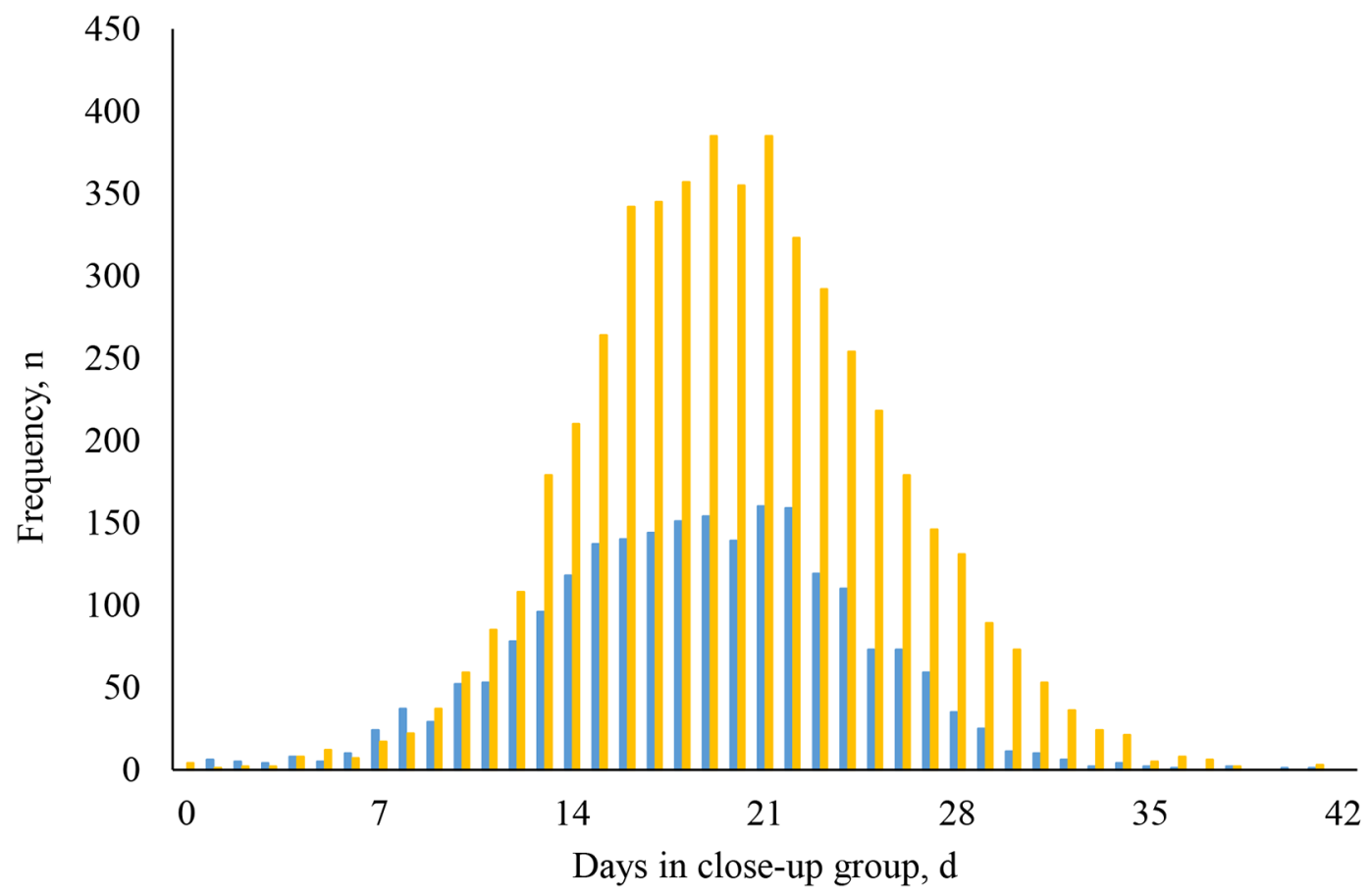

Figure 1. Frequency distribution of days in the close-up group for 7,567 cows from 1 commercial dairy farm. Blue bars represent primiparous cows $(\mathrm{n}=2,351)$. Yellow bars represent multiparous cows $(\mathrm{n}=5,216)$. 
In primiparous cows (Table 4), colostrum quantity was affected by month of calving $(P=0.004)$, sex of the calf $(P=0.050)$, and stillbirth $(P=0.036)$. Age at first calving $(P=0.079)$ and calving ease $(P=0.054$; calving ease $0=2.77 \pm 0.44 \mathrm{~kg}$; score $1=3.57 \pm$
$0.32 \mathrm{~kg}$; score $2=3.63 \pm 0.33 \mathrm{~kg} ;$ score $3=3.67 \pm$ $0.32 \mathrm{~kg}$ ) tended to affect colostrum quantity (Table 4). Gestation length $(P=0.525)$ and DINCU $(P=0.239)$ were not associated with colostrum quantity. Seasonal pattern of colostrum production in primiparous cows is

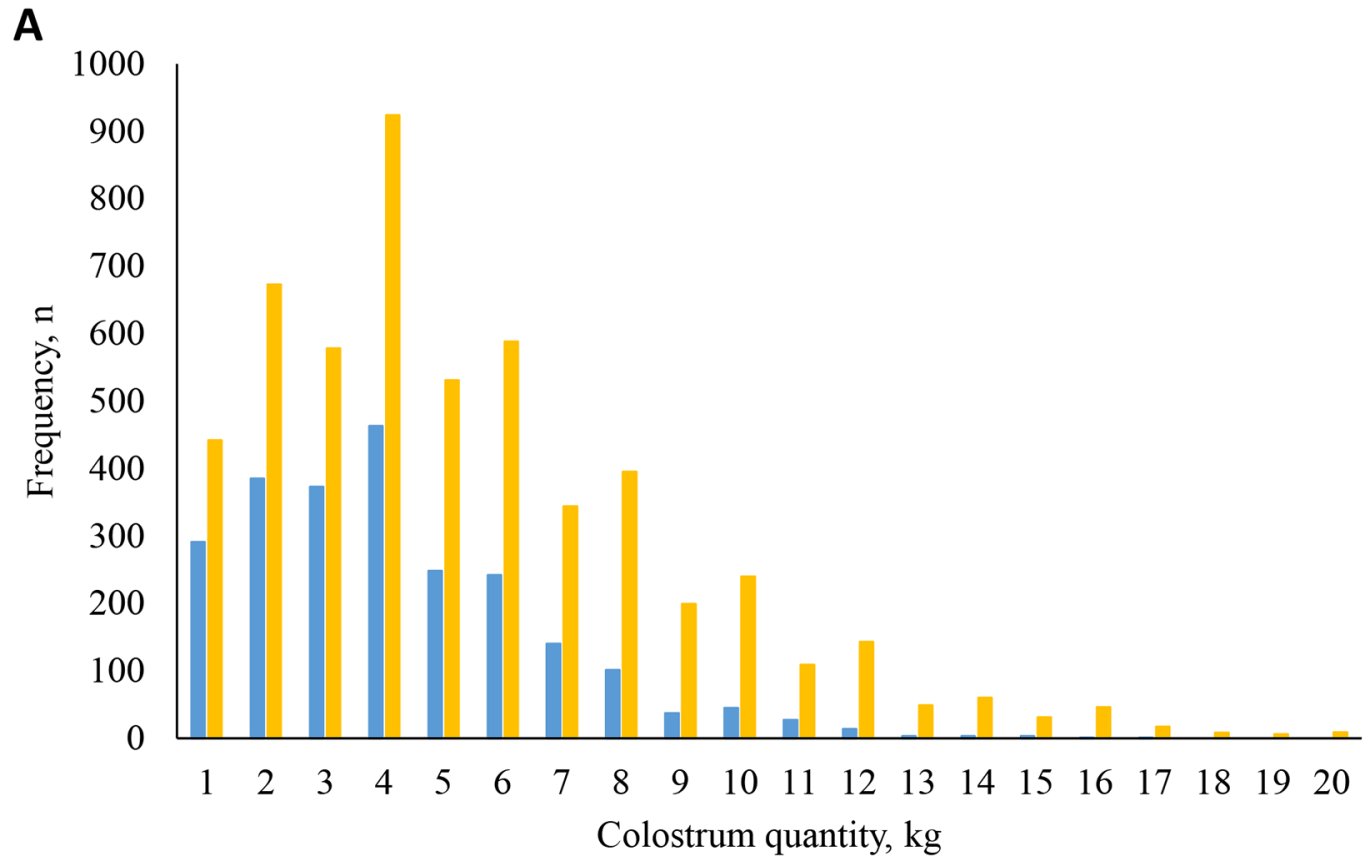

B

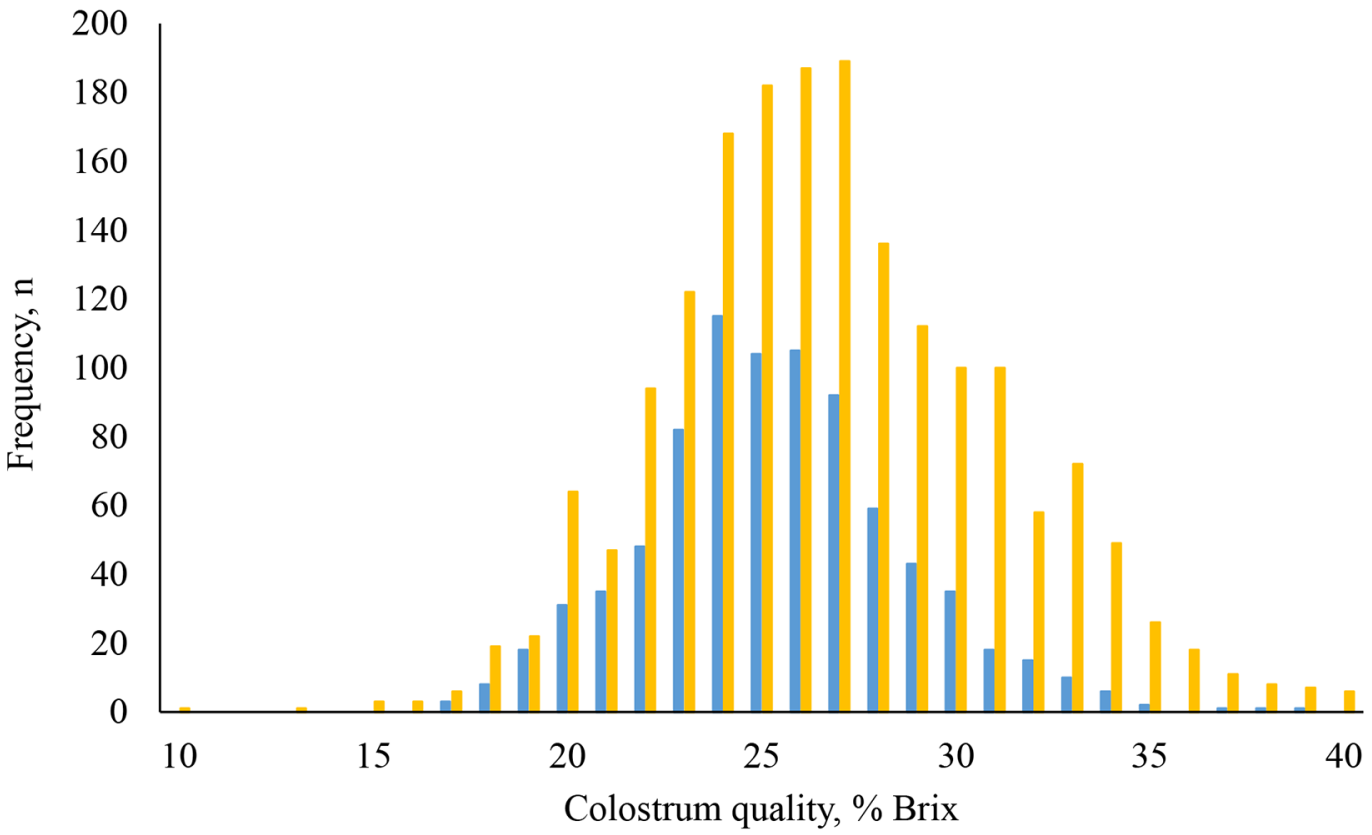

Figure 2. Frequency distribution of colostrum quantity (kg; panel A) for 7,567 Holstein cows (primiparous cows are displayed in blue, $\mathrm{n}=$ 2,351; multiparous cows are displayed in yellow, $\mathrm{n}=5,216$ ) that calved from January 1, 2018, to December 31, 2020, and colostrum quality (\% Brix; panel B) for 2,600 Holstein cows (primiparous cows are displayed in blue, $\mathrm{n}=817$; multiparous cows are displayed in yellow, $\mathrm{n}=1,783$ ) that calved in 2020. Colostrum quality was assessed using a digital Brix refractometer. 
presented in Figure 3. Colostrum quantity in primiparous cows was greatest in April (4.1 kg) and lowest in November $(3.2 \mathrm{~kg})$. Sex of the calf was associated with colostrum quantity (female singleton $=3.50 \pm 0.26 \mathrm{~kg}$; male singleton $=3.76 \pm 0.27 \mathrm{~kg}$; twins $=2.97 \pm 0.66$ $\mathrm{kg})$. Stillbirth was associated with reduced colostrum quantity in primiparous cows (stillbirth $=3.14 \pm 0.39$ $\mathrm{kg}$; no stillbirth $=3.68 \pm 0.31 \mathrm{~kg}$ ). A positive association tended to occur between age at first calving and colostrum quantity $(+0.07 \pm 0.04 \mathrm{~kg}$ for each month increase in age at first calving).

In multiparous cows (Table 5), colostrum quantity was affected by month of calving $(P=0.001)$, calving ease $(P=0.001)$, sex of the calf $(P=0.001)$, stillbirth $(P=0.003)$, milk yield in previous lactation $(P$ $=0.001)$, days spent in the far-off group $(P=0.001)$, and DINCU $(P=0.001)$. Gestation length $(P=0.334)$ was not associated with colostrum quantity. Seasonal pattern of colostrum production in multiparous cows is presented in Figure 4. Colostrum quantity in multiparous cows was greatest in May $(5.5 \mathrm{~kg})$ and lowest in October $(3.8 \mathrm{~kg})$. We observed a linear increase in colostrum quantity with calving difficulty (calving ease $0=4.23 \pm 0.26 \mathrm{~kg}$; score $1=4.77 \pm 0.21 \mathrm{~kg}$; score 2 $=4.98 \pm 0.22 \mathrm{~kg}$; score $3=5.30 \pm 0.22 \mathrm{~kg}$ ). Sex of the calf was associated with colostrum quantity (female singleton $=4.42 \pm 0.21 \mathrm{~kg}$; male singleton $=5.00 \pm$ $0.21 \mathrm{~kg}$; twins $=5.03 \pm 0.30 \mathrm{~kg})$. Stillbirth was associated with reduced colostrum quantity in multiparous cows (stillbirth $=4.24 \pm 0.38 \mathrm{~kg} ;$ no stillbirth $=5.39 \pm$ $0.11 \mathrm{~kg}$ ). A positive association occurred between milk yield in previous lactation and colostrum quantity. An increase in milk yield in previous lactation by $1,000 \mathrm{~kg}$ was associated with an increase in colostrum quantity by $0.1 \mathrm{~kg}$. Longer exposures to the far-off group $(0.05 \pm$ $0.003 \mathrm{~kg}$ for every day) and to the prepartum diet $(0.06$ $\pm 0.010 \mathrm{~kg}$ for every day) were associated with a linear increase in colostrum quantity (Figure 5).

Table 4. Association of colostrum quantity with management-related factors from 2,351 primiparous cows from 1 commercial dairy farm

\begin{tabular}{|c|c|c|c|c|c|}
\hline \multirow[b]{2}{*}{ Variable } & \multirow{2}{*}{$\begin{array}{c}\text { Estimate } \\
(\mathrm{kg})\end{array}$} & \multirow[b]{2}{*}{$\mathrm{SE}$} & \multicolumn{2}{|c|}{$95 \% \mathrm{CI}$} & \multirow[b]{2}{*}{$P$-value } \\
\hline & & & Lower CI & Upper CI & \\
\hline Intercept & 1.12 & 1.03 & -0.90 & 3.15 & 0.275 \\
\hline Age at first calving & 0.07 & 0.04 & -0.01 & 0.157 & 0.079 \\
\hline \multicolumn{6}{|l|}{ Gestation length $^{1}$} \\
\hline Normal & Referent & & & & \\
\hline Short & -0.11 & 0.18 & -0.47 & 0.25 & 0.551 \\
\hline Long & -0.20 & 0.22 & -0.64 & 0.24 & 0.373 \\
\hline \multicolumn{6}{|l|}{ Calving ease $^{2}$} \\
\hline 0 & Referent & & & & \\
\hline 1 & 0.80 & 0.32 & 0.17 & 1.42 & 0.013 \\
\hline 2 & 0.86 & 0.33 & 0.20 & 1.51 & 0.010 \\
\hline 3 & 0.90 & 0.33 & 0.26 & 1.55 & 0.006 \\
\hline \multicolumn{6}{|l|}{ Stillbirth } \\
\hline Alive & Referent & & & & \\
\hline Dead & -0.54 & 0.26 & -1.04 & -0.03 & 0.036 \\
\hline \multicolumn{6}{|l|}{ Sex of calf } \\
\hline Female & Referent & & & & \\
\hline Male & 0.25 & 0.11 & 0.03 & 0.48 & 0.026 \\
\hline Twins & -0.53 & 0.63 & -1.76 & 0.70 & 0.396 \\
\hline Days in the close-up group & 0.01 & 0.01 & -0.01 & 0.03 & 0.239 \\
\hline \multicolumn{6}{|l|}{ Month of calving } \\
\hline January & Referent & & & & \\
\hline February & 0.03 & 0.28 & -0.51 & 0.58 & 0.897 \\
\hline March & 0.06 & 0.28 & -0.49 & 0.60 & 0.840 \\
\hline April & 0.65 & 0.27 & 0.12 & 1.17 & 0.016 \\
\hline May & 0.53 & 0.27 & 0.01 & 1.11 & 0.050 \\
\hline June & 0.48 & 0.26 & -0.03 & 1.00 & 0.066 \\
\hline July & 0.25 & 0.27 & -0.29 & 0.78 & 0.368 \\
\hline August & 0.43 & 0.29 & -0.13 & 0.99 & 0.134 \\
\hline September & 0.17 & 0.26 & -0.35 & 0.68 & 0.523 \\
\hline October & -0.17 & 0.27 & -0.71 & 0.37 & 0.541 \\
\hline November & -0.20 & 0.27 & -0.73 & 0.34 & 0.474 \\
\hline December & 0.01 & 0.27 & -0.53 & 0.53 & 0.998 \\
\hline
\end{tabular}




\section{Colostrum Quality}

Average colostrum quality was $25.1 \%$ Brix, $24.7 \%$ Brix, and $27.6 \%$ Brix for cows in lactation 1, 2, and $\geq 3$, respectively. A histogram of colostrum quantity is presented in Figure 2.

In primiparous cows $(\mathrm{n}=817$; Table 6$)$, colostrum quality was affected only by month of calving $(P=$ $0.001)$. There tended to be a quadratic effect of DINCU $(P=0.057)$ on colostrum quality. Gestation length (GL) tended to be associated with colostrum quality (short GL $=24.9 \pm 2.3 \%$ Brix; normal GL $=25.3 \pm$ $2.3 \%$ Brix; long GL $=26.4 \pm 2.3 \%$ Brix). Colostrum quality in primiparous cows was greatest in December (26.8\% Brix) and lowest in August (23.9\% Brix).

In multiparous cows $(\mathrm{n}=1,783$; Table 7$)$, colostrum quality was affected by parity $(P=0.001)$, month of calving $(P=0.001)$, milk yield in previous lactation $(P$ $=0.019)$, and colostrum quantity $(P=0.001)$. Stillbirth tended to affect colostrum quality $(P=0.089$; stillbirth $=27.3 \pm 2.8 \%$ Brix; no stillbirth $=25.9 \pm$ $2.7 \%$ Brix $)$. Gestation length $(P=0.133)$ and DINCU
$(P=0.134)$ had no effect on colostrum quality. Cows in parity 3 or greater $(27.9 \pm 2.7 \%$ Brix $)$ had better quality compared with cows in lactation 2 (25.2 $\pm 2.7 \%$ Brix). Colostrum quality in multiparous cows was greatest in February (27.5\% Brix) and lowest in August $(25.7 \%$ Brix). Milk yield in previous lactation was negatively associated with colostrum quality. An increase in milk yield in previous lactation by $1,000 \mathrm{~kg}$ was associated with a decrease in colostrum quality by $0.13 \%$ Brix. Also, colostrum quantity was negatively associated with colostrum quality. An increase in colostrum quantity of $1 \mathrm{~kg}$ was associated with a decrease in colostrum quality of $0.27 \%$ Brix (Figure 3).

\section{DISCUSSION}

The objective of this study was to evaluate the association of management-related factors in dry cows and colostrum quantity and quality in Holstein cows on one commercial dairy farm. In primiparous cows, length of exposure to a prepartum diet was not associated with

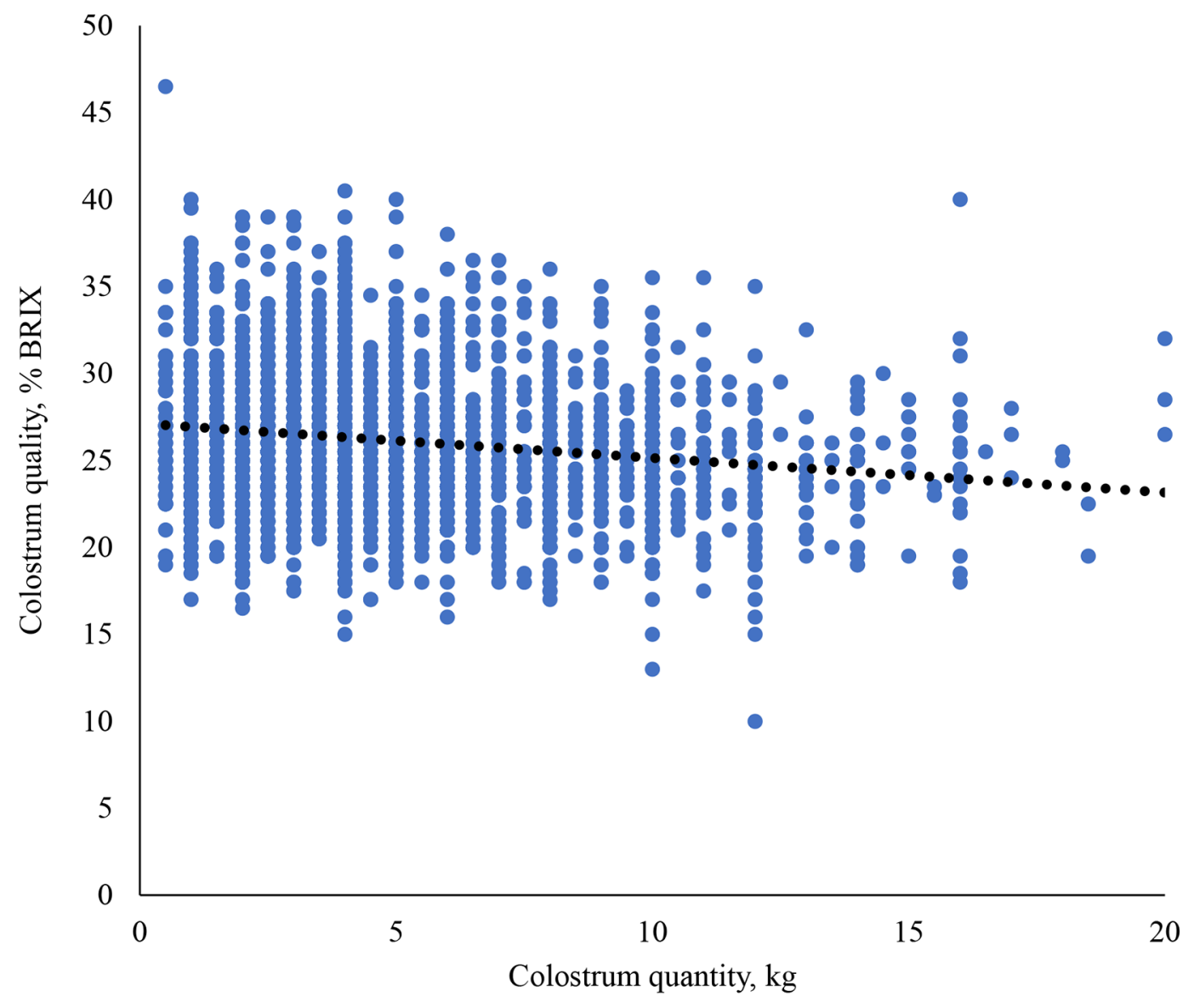

Figure 3. Association between colostrum quantity $(\mathrm{kg})$ and colostrum quality (\% Brix) for 2,600 Holstein cows that calved in 2020. Colostrum quality was assessed using a digital Brix refractometer. 
colostrum quantity or colostrum quality. Colostrum quantity was affected by time of the year, sex of the calf, and stillbirth. Colostrum quality was affected only by time of the year.

In multiparous cows, however, length of exposure to the far-off and close-up diet was associated with colostrum quantity. Other contributing factors were time of the year, sex of the calf, stillbirth, calving ease, and milk yield in previous lactation. Colostrum quality was affected by parity, gestation length, milk yield in previous lactation, and colostrum quantity.

Typically, 2 diets in the dry period have been adopted by commercial dairy farms. The diet fed within the last 3 to $4 \mathrm{wk}$ of gestation generally has higher energy and protein contents (Van Saun and Sniffen, 2014). The diets fed in this study resembled this approach. It has been shown that a prepartum diet with a nega- tive DCAD leads to an improvement in periparturient mineral balance, reduced diseases risk, and improved milk yield, particularly in multiparous cows (Lean et al., 2019; Santos et al., 2019). In primiparous cows, feeding a negative DCAD diet prepartum had a negative effect on DMI and milk yield but was favorable for postpartum risk for retained placenta and metritis (Lean et al., 2019). Until recently little evidence has existed regarding the ideal duration of feeding such a prepartum diet. Two recent observational studies reported reduced morbidity and improved milk production when either Holstein cows (Vieira-Neto et al., 2021) or Jersey cows (Chebel, 2021) were exposed to a prepartum diet for $28 \mathrm{~d}$. Shorter or longer exposure led to unfavorable outcomes. Unfortunately, none of these studies assessed the association of length of exposure to a prepartum diet on colostrum quantity or quality. Results from our

Table 5. Association of colostrum quantity with management-related factors from 5,216 multiparous cows from 1 commercial dairy farm

\begin{tabular}{|c|c|c|c|c|c|}
\hline \multirow[b]{2}{*}{ Variable } & \multirow{2}{*}{$\begin{array}{c}\text { Estimate } \\
(\mathrm{kg})\end{array}$} & \multirow[b]{2}{*}{$\mathrm{SE}$} & \multicolumn{2}{|c|}{$95 \% \mathrm{CI}$} & \multirow[b]{2}{*}{$P$-value } \\
\hline & & & Lower CI & Upper CI & \\
\hline Intercept & 0.13 & 0.44 & -0.72 & 0.99 & 0.757 \\
\hline \multicolumn{6}{|l|}{ Gestation length ${ }^{1}$} \\
\hline Normal & Referent & & & & \\
\hline Short & -0.28 & 0.22 & -0.71 & 0.15 & 0.204 \\
\hline Long & 0.12 & 0.14 & -0.14 & 0.39 & 0.358 \\
\hline \multicolumn{6}{|l|}{ Calving ease $^{2}$} \\
\hline 0 & Referent & & & & \\
\hline 1 & 0.54 & 0.17 & 0.20 & 0.88 & 0.001 \\
\hline 2 & 0.75 & 0.20 & 0.35 & 1.14 & 0.001 \\
\hline 3 & 1.06 & 0.19 & 0.68 & 1.44 & 0.001 \\
\hline \multicolumn{6}{|l|}{ Stillbirth } \\
\hline Alive & Referent & & & & \\
\hline Dead & -1.15 & 0.39 & -1.91 & -0.40 & 0.001 \\
\hline \multicolumn{6}{|l|}{ Sex of the calf } \\
\hline Female & Referent & & & & \\
\hline Male & 0.58 & 0.09 & 0.40 & 0.76 & 0.001 \\
\hline Twins & 0.61 & 0.28 & 0.05 & 1.16 & 0.032 \\
\hline Previous 305-d milk yield ${ }^{3}$ & 0.10 & 0.02 & 0.06 & 0.14 & 0.001 \\
\hline Days in the far-off group & 0.05 & 0.01 & 0.05 & 0.06 & 0.001 \\
\hline Day in the close-up group & 0.06 & 0.01 & 0.04 & 0.08 & 0.001 \\
\hline \multicolumn{6}{|l|}{ Month of calving } \\
\hline January & Referent & & & & \\
\hline February & 0.19 & 0.24 & -0.28 & 0.66 & 0.417 \\
\hline March & 0.18 & 0.24 & -0.28 & 0.65 & 0.439 \\
\hline April & 0.58 & 0.24 & 0.12 & 1.05 & 0.010 \\
\hline May & 1.08 & 0.24 & 0.62 & 1.55 & 0.001 \\
\hline June & 0.73 & 0.23 & 0.28 & 1.17 & 0.001 \\
\hline July & 0.79 & 0.23 & 0.33 & 1.24 & 0.001 \\
\hline August & 0.38 & 0.22 & -0.04 & 0.81 & 0.075 \\
\hline September & -0.62 & 0.22 & -1.05 & -0.19 & 0.001 \\
\hline October & -0.66 & 0.22 & -1.10 & -0.22 & 0.001 \\
\hline November & -0.40 & 0.22 & -0.83 & 0.03 & 0.069 \\
\hline December & 0.27 & 0.22 & -0.16 & 0.69 & 0.216 \\
\hline
\end{tabular}

${ }^{1}$ Gestation length was categorized as short (range between 257 and $269 \mathrm{~d}$ of gestation), normal (270-280 d), or long (281-293 d).

${ }^{2}$ Calving assistance was recorded using a 4 -point scale $(0=$ not observed; $1=$ no assistance; $2=$ assistance by 1 person; 3 = assistance by at least 2 persons).

${ }^{3}$ Milk yield in the previous lactation, $\times 1,000 \mathrm{~kg}$. 


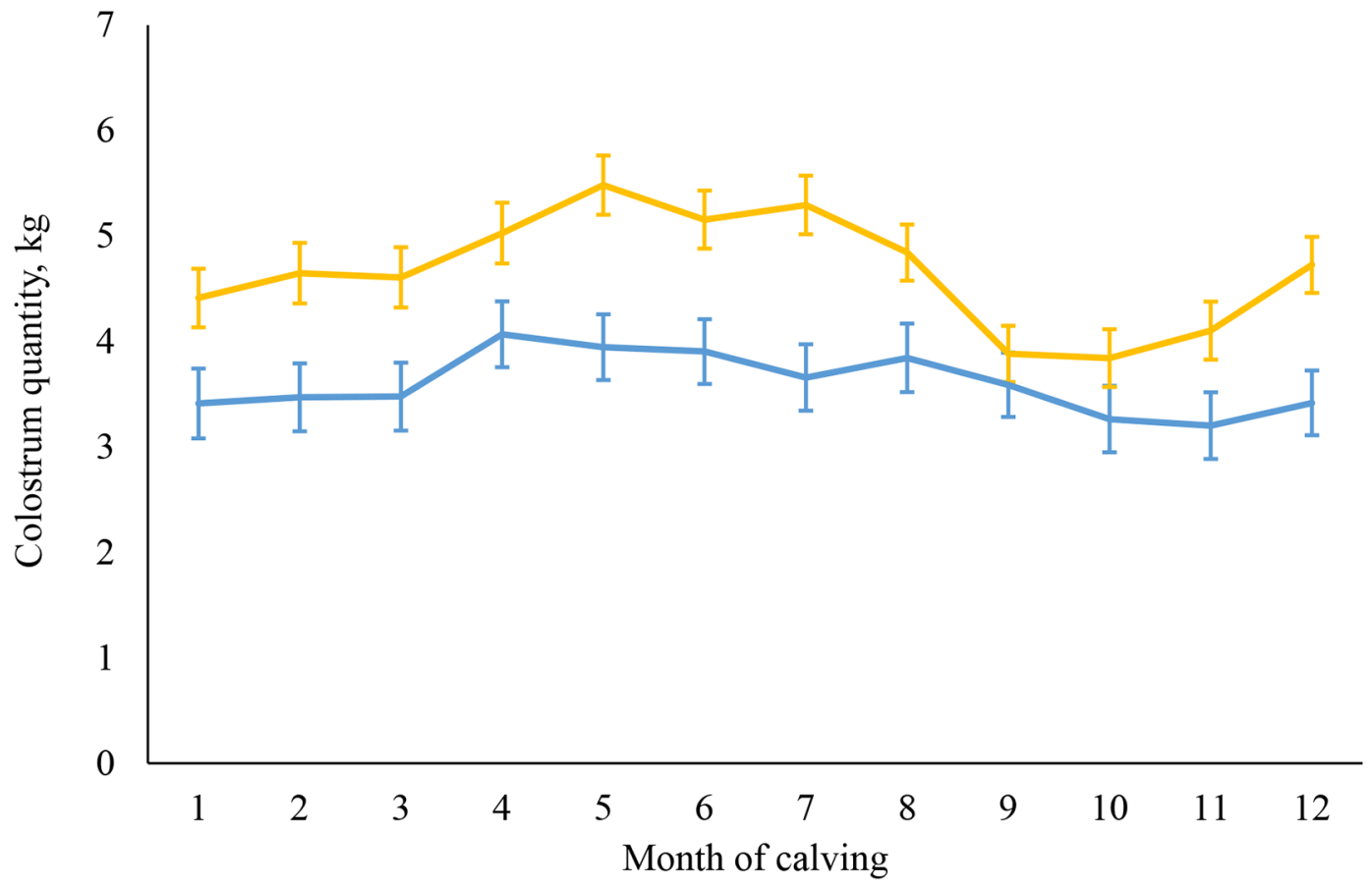

Figure 4. Seasonal pattern of colostrum quantity ( $\mathrm{kg} \pm \mathrm{SEM})$ for 7,567 cows from 1 commercial dairy farm. The blue line represents primiparous cows $(\mathrm{n}=2,351)$. The yellow line represents multiparous cows $(\mathrm{n}=5,216)$. From the final models for primiparous and multiparous cows, predicted colostrum quantity was plotted against month of calving (1-12 = January through December). In primiparous cows, the model contained the following fixed effects: month of calving $(P=0.004)$, sex of the calf $(P=0.050)$, stillbirth $(P=0.036)$, age at first calving $(P$ $=0.079)$, calving ease $(P=0.054)$, gestation length $(P=0.525)$, days spent in the close-up pen $(P=0.239)$. In multiparous cows, the model contained the following fixed effects: month of calving $(P=0.001)$, calving ease $(P=0.001)$, sex of the calf $(P=0.001)$, stillbirth $(P=0.003)$, milk yield in previous lactation $(P=0.001)$, days spent in the far-off group $(P=0.001)$, days spent in the close-up pen $(P=0.001)$, and gestation length $(P=0.334)$.

Table 6. Association of colostrum quality with management-related factors from 817 primiparous cows from 1 commercial dairy farm; colostrum quality was assessed using a digital Brix refractometer

\begin{tabular}{|c|c|c|c|c|c|}
\hline \multirow[b]{2}{*}{ Variable } & \multirow{2}{*}{$\begin{array}{l}\text { Estimate } \\
\text { (\% Brix) }\end{array}$} & \multirow[b]{2}{*}{$\mathrm{SE}$} & \multicolumn{2}{|c|}{$95 \% \mathrm{CI}$} & \multirow[b]{2}{*}{$P$-value } \\
\hline & & & Lower CI & Upper CI & \\
\hline Intercept & 23.48 & 2.83 & 17.93 & 29.04 & 0.001 \\
\hline \multicolumn{6}{|l|}{ Gestation length $^{1}$} \\
\hline Normal & Referent & & & & \\
\hline Short & -0.36 & 0.49 & -1.33 & 0.60 & 0.463 \\
\hline Long & 1.09 & 0.50 & 0.10 & 2.07 & 0.030 \\
\hline DINCU $^{2}$ & 0.24 & 0.15 & -0.05 & 0.53 & 0.107 \\
\hline DINCU $\times$ DINCU & -0.01 & 0.00 & -0.01 & 0.01 & 0.057 \\
\hline \multicolumn{6}{|l|}{ Month of calving } \\
\hline January & Referent & & & & \\
\hline February & -0.32 & 0.59 & -1.48 & 0.84 & 0.584 \\
\hline March & -0.09 & 0.63 & -1.32 & 1.15 & 0.887 \\
\hline April & -0.76 & 0.58 & -1.91 & 0.39 & 0.193 \\
\hline May & -0.80 & 0.59 & -1.96 & 0.37 & 0.180 \\
\hline June & -0.85 & 0.60 & -2.03 & 0.33 & 0.157 \\
\hline July & -1.08 & 0.56 & -2.17 & 0.01 & 0.053 \\
\hline August & -1.63 & 0.59 & -2.78 & -0.48 & 0.006 \\
\hline September & -0.58 & 0.55 & -1.67 & 0.51 & 0.297 \\
\hline October & 0.42 & 0.60 & -0.77 & 1.60 & 0.490 \\
\hline November & 0.98 & 0.62 & -0.24 & 2.21 & 0.114 \\
\hline December & 1.30 & 0.62 & 0.07 & 2.52 & 0.038 \\
\hline
\end{tabular}

${ }^{1}$ Gestation length was categorized as short (range between 257 and $269 \mathrm{~d}$ of gestation), normal (270-280 d), or long (281 and $293 \mathrm{~d})$.

${ }^{2}$ Days spent in the close-up group. 
study suggest that length of exposure to a prepartum diet was associated with colostrum quantity in multiparous cows but not in primiparous cows. A linear increase in colostrum quantity occurred with increasing DINCU $(10 \mathrm{~d}=4.94 \pm 0.19 \mathrm{~kg} ; 20 \mathrm{~d}=5.19 \pm 0.06$ $\mathrm{kg} ; 30 \mathrm{~d}=5.86 \pm 0.12 \mathrm{~kg}$ ). The designs of our study and of the cited studies do not allow attribution of effects to the length of exposure to DCAD diet, as other components were not accounted for.

We observed a negative association between DINCU and colostrum quantity. This is in agreement with a randomized controlled experiment in which a short stay in the close-up pen (10 d vs. $21 \mathrm{~d})$ resulted in reduced colostrum quantity (Farahani et al., 2017). Contrary to our findings, 2 previous studies showed no effect on either colostrum quantity or quality when cows were fed a close-up diet with a negative DCAD for $42 \mathrm{~d}$ versus $21 \mathrm{~d}$ (Weich et al., 2013; Lopera et al., 2018). Mammary development and colostrogenesis at the end of gestation led to an increased demand for energy and protein (Van Saun and Sniffen, 2014). Therefore, short exposure to a well formulated prepartum diet might result in insufficient supply of nutrients. Apart from nutrient supply, a certain dry period length is necessary for mammary involution (Collier et al., 2012). Reducing the length of the dry period from 60 to $40 \mathrm{~d}$ decreased the quantity of colostrum ( 8.9 vs. $6.8 \mathrm{~kg}$; Grusenmeyer et al., 2006). Cows with a 60-d dry period produced more colostrum compared with cows with a 0 -d or 30-d dry period (7.7 vs. 5.3 vs. $5.1 \mathrm{~kg}$; Mayasari et al., 2015). Dairy cows, specifically cows at the end of their first lactation, require a 60-d dry period length for normal mammary epithelial cell turnover and regeneration. Extending lactation during the last 8 wk of gestation changes the patterns of cell apoptosis and proliferation (Pezeshki et al., 2010). If lactation is sustained, old or senescent cells cannot be replaced with new cells, resulting in an epithelium with less prolific capacity. The majority of studies on customizing the dry period length have focused on milk production. Results from our study provide evidence that the same concept applies to colostrogenesis. Apart from DINCU, days spent in the far-off group had also an effect on colostrum quantity.

The seasonal pattern of colostrum quantity is similar to a study using observational data from a Jersey

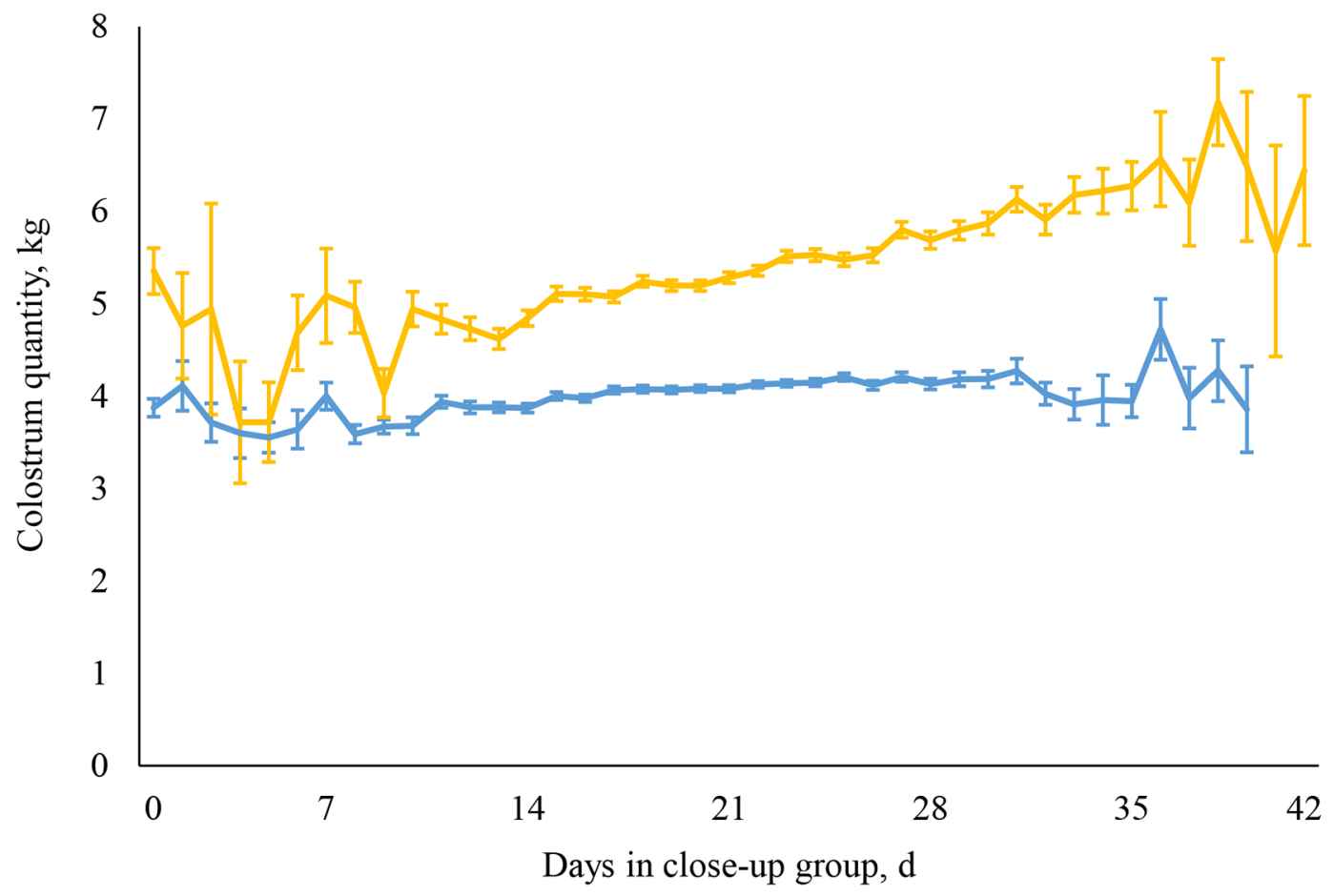

Figure 5. Association of days spent in the close-up pen and of colostrum quantity ( $\mathrm{kg} \pm \mathrm{SEM}$ ) for 7,567 cows from 1 commercial dairy farm. The blue line represents primiparous cows $(\mathrm{n}=2,351)$. The yellow line represents multiparous cows $(\mathrm{n}=5,216)$. From the final models for primiparous and multiparous cows, predicted colostrum quantity was plotted against month of calving. In primiparous cows, the model contained the following fixed effects: month of calving $(P=0.004)$, sex of the calf $(P=0.050)$, stillbirth $(P=0.036)$, age at first calving $(P=0.079)$, calving ease $(P=0.054)$, gestation length $(P=0.525)$, days spent in the close-up pen $(P=0.239)$. In multiparous cows, the model contained the following fixed effects: month of calving $(P=0.001)$, calving ease $(P=0.001)$, sex of the calf $(P=0.001)$, stillbirth $(P=0.003)$, milk yield in previous lactation $(P=0.001)$, days spent in the far-off group $(P=0.001)$, days spent in the close-up pen $(P=0.001)$, and gestation length $(P=0.334)$. 
Table 7. Association of colostrum quality with management-related factors from 1,783 multiparous cows from 1 commercial dairy farm; colostrum quality was assessed using a digital Brix refractometer

\begin{tabular}{|c|c|c|c|c|c|}
\hline \multirow[b]{2}{*}{ Variable } & \multirow{2}{*}{$\begin{array}{l}\text { Estimate } \\
\text { (\% Brix) }\end{array}$} & \multirow[b]{2}{*}{$\mathrm{SE}$} & \multicolumn{2}{|c|}{$95 \% \mathrm{CI}$} & \multirow[b]{2}{*}{$P$-value } \\
\hline & & & Lower CI & Upper CI & \\
\hline Intercept & 27.19 & 2.87 & 21.57 & 32.82 & 0.001 \\
\hline \multicolumn{6}{|l|}{ Gestation length ${ }^{1}$} \\
\hline Normal & Referent & & & & \\
\hline Short & -0.59 & 0.38 & -1.33 & 0.16 & 0.122 \\
\hline Long & -0.30 & 0.29 & -0.86 & 0.26 & 0.294 \\
\hline \multicolumn{6}{|l|}{ Stillbirth } \\
\hline Alive & Referent & & & & \\
\hline Dead & 1.38 & 0.81 & -0.21 & 2.98 & 0.089 \\
\hline \multicolumn{6}{|l|}{ Parity } \\
\hline Lactation 2 & Referent & & & & \\
\hline Lactation $3+$ & 2.76 & 0.18 & 2.41 & 3.11 & 0.001 \\
\hline Colostrum quantity, kg & -0.27 & 0.03 & -0.32 & -0.22 & 0.001 \\
\hline Previous $305-\mathrm{d}$ milk yield ${ }^{2}$ & -0.13 & 0.05 & -0.23 & -0.02 & 0.019 \\
\hline Days in the close-up group & 0.03 & 0.02 & -0.01 & 0.07 & 0.134 \\
\hline \multicolumn{6}{|l|}{ Month of calving } \\
\hline January & Referent & & & & \\
\hline February & 1.12 & 0.48 & 0.18 & 2.07 & 0.020 \\
\hline March & -0.11 & 0.48 & -1.05 & 0.83 & 0.814 \\
\hline April & 0.39 & 0.47 & -0.53 & 1.31 & 0.403 \\
\hline May & 0.19 & 0.47 & -0.73 & 1.11 & 0.686 \\
\hline June & -0.24 & 0.47 & -1.17 & 0.68 & 0.606 \\
\hline July & -0.14 & 0.44 & -1.01 & 0.72 & 0.746 \\
\hline August & -0.70 & 0.43 & -1.54 & 0.15 & 0.106 \\
\hline September & 0.78 & 0.45 & -0.10 & 1.65 & 0.083 \\
\hline October & 0.39 & 0.44 & -0.48 & 1.26 & 0.382 \\
\hline November & -0.31 & 0.46 & -1.21 & 0.59 & 0.499 \\
\hline December & 0.94 & 0.45 & 0.06 & 1.82 & 0.037 \\
\hline
\end{tabular}

herd (Gavin et al., 2018). These authors speculated that photoperiod length and the associated hormonal patterns (i.e., melatonin and prolactin) were associated with colostrum quantity. The effect of photoperiod on the mammary gland is mediated by light signals in the eye that alter secretion of melatonin by the pineal gland (Hernandez et al., 2017). Long days lead to melatonin suppression, and short days are associated with a rapid increase in melatonin release. It has been shown that a short-day photoperiod in dry cows leads to an increase in milk production by $10 \%$ compared with dry cows experiencing a long-day photoperiod (Lacasse et al., 2014). None of those studies assessed colostrum quantity. Therefore, it remains speculative whether the mechanism behind the seasonal pattern of colostrum quantity is comparable to the effect of photoperiod on milk production during lactation.

We found a negative association between colostrum quantity and quality, which has been described previously (Pritchett et al., 1991; Sutter et al., 2019). The reason may be a dilutional effect of colostral IgG. The onset of lactation is associated with a higher secretion of lactose into the udder, which also involves a higher water diffusion, whereas the absolute amount of $\operatorname{IgG}$ remains the same (Baumrucker et al., 2010; Morin et al., 2010).

We observed a difference in colostrum quantity and quality among parities, with older cows producing more and better-quality colostrum. The concentration of colostral IgG increases with increasing parity until the fourth lactation (Gulliksen et al., 2008), probably due to longer exposure of older cows to antigens during their life. Several studies have reported that colostrum quality was significantly better among cows in the third lactation than among cows in second lactation (Conneely et al., 2013; Angulo et al., 2015; Sutter et al., 2019). Furthermore, the transfer of IgG into the udder might be linked to more advanced maturation of the mammary gland.

A genetic influence on colostrum quantity may also exist, as has been shown recently in Jersey cattle (Kiser et al., 2019). Interestingly, for Holstein cows, colostrum quantity does not appear to be heritable, but several aspects of colostrum quality may be (Soufleri et al., 2019). More research is needed to confirm these results.

This study was carried out on a single farm; therefore, the results need to be validated with a multicentric study design. Future studies should strive to imple- 
ment a randomized controlled study design and need to evaluate the effect of short DINCU on colostrum quantity in more detail.

Colostrum quality was assessed using digital Brix refractometry only in a subsample of animals. The gold standard to assess $\operatorname{IgG}$ status in colostrum is radial immunodiffusion, despite well-known methodological challenges. In previous studies, the correlation between radial immunodiffusion and digital refractometry ranged from 0.64 to 0.87 (Bielmann et al., 2010; Vandeputte et al., 2014; Bartier et al., 2015; Morrill et al., 2015). Average colostrum quality in our study was $25.1 \%$ Brix, $24.7 \%$ Brix, and $27.6 \%$ Brix for cows in lactation 1,2 , and $\geq 3$, respectively. This is in agreement with another observational study on a large Holstein farm using a digital Brix refractometer (Zentrich et al., 2019; median 23.2\%, ranging from 9.3 to $42.0 \%$ Brix).

\section{CONCLUSIONS}

Using observational data from one farm, we found that colostrum quantity and quality were affected by calving month and some other cow factors. Length of exposure to far-off and close-up diets played a minor role for colostrum production in multiparous cows. Variation in colostrum production across the year might have the potential to affect calf morbidity and mortality through inadequate colostrum supply. Banking high-quality colostrum might be one option to address fluctuations. Future intervention studies using multiple farms need to elucidate whether management of the photoperiod or length of exposure to close-up diets, or both, can help to optimize colostrum production.

\section{ACKNOWLEDGMENTS}

The authors thank the collaborating farm and the farm personnel for their kind support. The study was funded in part by Tiergyn e. V. (Berlin, Germany). The authors have not stated any other conflicts of interest.

\section{REFERENCES}

Abuelo, A., F. Cullens, A. Hanes, and J. L. Brester. 2021. Impact of 2 versus 1 colostrum meals on failure of transfer of passive immunity, pre-weaning morbidity and mortality, and performance of dairy calves in a large dairy herd. Animals (Basel) 11:782. https://doi .org/10.3390/ani11030782.

Angulo, J., L. M. Gómez, L. Mahecha, E. Mejía, J. Henao, and C. Mesa. 2015. Calf's sex, parity and the hour of harvest after calving affect colostrum quality of dairy cows grazing under high tropical conditions. Trop. Anim. Health Prod. 47:699-705. https://doi .org/10.1007/s11250-015-0781-z.

Annen, E. L., R. J. Collier, M. A. McGuire, and J. L. Vicini. 2004. Effects of dry period length on milk yield and mammary epithelial cells. J. Dairy Sci. 87:E66-E76. https://doi.org/10.3168/jds.S0022 -0302(04)70062-4.
Bartier, A. L., M. C. Windeyer, and L. Doepel. 2015. Evaluation of on-farm tools for colostrum quality measurement. J. Dairy Sci. 98:1878-1884. https://doi.org/10.3168/jds.2014-8415.

Baumrucker, C. R., A. M. Burkett, A. L. Magliaro-Macrina, and C. D. Dechow. 2010. Colostrogenesis: Mass transfer of immunoglobulin $\mathrm{G}_{1}$ into colostrum. J. Dairy Sci. 93:3031-3038. https://doi.org/10 $.3168 /$ jds.2009-2963.

Bell, A. W., W. S. Burhans, and T. R. Overton. 2000. Protein nutrition in late pregnancy, maternal protein reserves and lactation performance in dairy cows. Proc. Nutr. Soc. 59:119-126. https:// doi.org/10.1017/S0029665100000148.

Bielmann, V., J. Gillan, N. R. Perkins, A. L. Skidmore, S. Godden, and K. E. Leslie. 2010. An evaluation of Brix refractometry instruments for measurement of colostrum quality in dairy cattle. J. Dairy Sci. 93:3713-3721. https://doi.org/10.3168/jds.2009-2943.

Brandon, M. R., D. L. Watson, and A. K. Lascelles. 1971. The mechanism of transfer of immunoglobulin into mammary secretion of cows. Aust. J. Exp. Biol. Med. Sci. 49:613-623. https://doi.org/10 $.1038 /$ icb.1971.67.

Chebel, R. C. 2021. Associations between days on close-up diets and immune responses prepartum, metabolites peripartum, and risk of postpartum diseases in Jersey cows. J. Dairy Sci. 104:7135-7153. https://doi.org/10.3168/jds.2020-19700.

Collier, R. J., E. L. Annen-Dawson, and A. Pezeshki. 2012. Effects of continuous lactation and short dry periods on mammary function and animal health. Animal 6:403-414. https://doi.org/10.1017/ S1751731111002461.

Conneely, M., D. P. Berry, R. Sayers, J. P. Murphy, I. Lorenz, M. L. Doherty, and E. Kennedy. 2013. Factors associated with the concentration of immunoglobulin $\mathrm{G}$ in the colostrum of dairy cows. Animal 7:1824-1832. https://doi.org/10.1017/S1751731113001444.

Dohoo, P. J., S. W. Martin, and H. Stryhn. 2009. Veterinary Epidemiologic Research. 2nd ed. University of Prince Edward Island.

Faber, S. N., N. E. Faber, T. C. Mccauley, and R. L. Ax. 2005. Case study: Effects of colostrum ingestion on lactational performance. Prof. Anim. Sci. 21:420-425. https://doi.org/10.15232/S1080 $-7446(15) 31240-7$.

Farahani, T. A., H. Amanlou, and M. Kazemi-Bonchenari. 2017. Effects of shortening the close-up period length coupled with increased supply of metabolizable protein on performance and metabolic status of multiparous Holstein cows. J. Dairy Sci. 100:61996217. https://doi.org/10.3168/jds.2016-12263.

Gavin, K., H. Neibergs, A. Hoffman, J. N. Kiser, M. A. Cornmesser, S. A. Haredasht, B. Martínez-López, J. R. Wenz, and D. A. Moore. 2018. Low colostrum yield in Jersey cattle and potential risk factors. J. Dairy Sci. 101:6388-6398. https://doi.org/10.3168/ jds.2017-14308.

Godden, S. M., J. E. Lombard, and A. R. Woolums. 2019. Colostrum management for dairy calves. Vet. Clin. North Am. Food Anim. Pract. 35:535-556. https://doi.org/10.1016/j.cvfa.2019.07.005.

Grusenmeyer, D. J., C.M. Ryan, D.M. Galton, and T.R. Overton. 2006. Shortening the dry period from 60 to 40 days does not affect colostrum quality but decreases colostrum yield by Holstein cows. J. Dairy Sci. 89(Suppl. 1):336.

Gulliksen, S. M., K. I. Lie, L. Sølverød, and O. Østerås. 2008. Risk factors associated with colostrum quality in Norwegian dairy cows. J. Dairy Sci. 91:704-712. https://doi.org/10.3168/jds.2007-0450.

Heinrichs, A. J., and B. S. Heinrichs. 2011. A prospective study of calf factors affecting first-lactation and lifetime milk production and age of cows when removed from the herd. J. Dairy Sci. 94:336-341. https://doi.org/10.3168/jds.2010-3170.

Hernandez, L. L., G. E. Dahl, and R. J. Collier. 2017. Regulation of the lactating mammary gland. Pages 829-839 in Large Dairy Herd Management. 3rd ed. D. K. Beede, ed. American Dairy Science Association.

Husnain, A., and J. E. P. Santos. 2019. Meta-analysis of the effects of prepartum dietary protein on performance of dairy cows. J. Dairy Sci. 102:9791-9813. https://doi.org/10.3168/jds.2018-16043.

Jones, C. M., R. E. James, J. D. Quigley III, and M. L. McGilliard. 2004. Influence of pooled colostrum or colostrum replacement on IgG and evaluation of animal plasma in milk replacer. J. Dairy Sci. 
87:1806-1814. https://doi.org/10.3168/jds.S0022-0302(04)73337

Kiser, J. N., M. A. Cornmesser, K. Gavin, A. Hoffman, D. A. Moore, and H. L. Neibergs. 2019. Rapid Communication: Genome-wide association analyses identify loci associated with colostrum production in Jersey cattle. J. Anim. Sci. 97:1117-1123. https://doi .org/10.1093/jas/sky482.

Klusmeyer, T. H., A. C. Fitzgerald, A. C. Fabellar, J. M. Ballam, R. A. Cady, and J. L. Vicini. 2009. Effect of recombinant bovine somatotropin and a shortened or no dry period on the performance of lactating dairy cows. J. Dairy Sci. 92:5503-5511. https://doi .org/10.3168/jds.2009-2390.

Lacasse, P., C. M. Vinet, and D. Petitclerc. 2014. Effect of prepartum photoperiod and melatonin feeding on milk production and prolactin concentration in dairy heifers and cows. J. Dairy Sci. 97:3589-3598. https://doi.org/10.3168/jds.2013-7615.

Lean, I. J., J. E. P. Santos, E. Block, and H. M. Golder. 2019. Effects of prepartum dietary cation-anion difference intake on production and health of dairy cows: A meta-analysis. J. Dairy Sci. 102:21032133. https://doi.org/10.3168/jds.2018-14769.

Lopera, C., R. Zimpel, A. Vieira-Neto, F. R. Lopes, W. Ortiz, M. Poindexter, B. N. Faria, M. L. Gambarini, E. Block, C. D. Nelson, and J. E. P. Santos. 2018. Effects of level of dietary cation-anion difference and duration of prepartum feeding on performance and metabolism of dairy cows. J. Dairy Sci. 101:7907-7929. https://doi .org/10.3168/jds.2018-14580.

Mann, S., F. A. Leal Yepes, T. R. Overton, A. L. Lock, S. V. Lamb, J. J. Wakshlag, and D. V. Nydam. 2016. Effect of dry period dietary energy level in dairy cattle on volume, concentrations of immunoglobulin G, insulin, and fatty acid composition of colostrum. J. Dairy Sci. 99:1515-1526. https://doi.org/10.3168/jds.2015-9926.

Mayasari, N., G. de Vries Reilingh, M. G. B. Nieuwland, G. J. Remmelink, H. K. Parmentier, B. Kemp, and A. T. M. van Knegsel. 2015. Effect of maternal dry period length on colostrum immunoglobulin content and on natural and specific antibody titers in calves. J. Dairy Sci. 98:3969-3979. https://doi.org/10.3168/jds.2014-8753.

Morin, D. E., S. V. Nelson, E. D. Reid, D. W. Nagy, G. E. Dahl, and P. D. Constable. 2010. Effect of colostral volume, interval between calving and first milking, and photoperiod on colostral IgG concentrations in dairy cows. J. Am. Vet. Med. Assoc. 237:420-428. https://doi.org/10.2460/javma.237.4.420.

Morrill, K. M., K. E. Robertson, M. M. Spring, A. L. Robinson, and H. D. Tyler. 2015. Validating a refractometer to evaluate immunoglobulin $\mathrm{G}$ concentration in Jersey colostrum and the effect of multiple freeze-thaw cycles on evaluating colostrum quality. J. Dairy Sci. 98:595-601. https://doi.org/10.3168/jds.2014-8730.

NRC. 2001. Nutrient Requirements of Dairy Cattle. 7th ed. Natl. Acad. Press.

Pezeshki, A., A. V. Capuco, B. de Spiegeleer, L. Peelman, M. Stevens, R. J. Collier, and C. Burvenich. 2010. An integrated view on how the management of the dry period length of lactating cows could affect mammary biology and defence. J. Anim. Physiol. Anim. Nutr. (Berl.) 94:e7-e30. https://doi.org/10.1111/j.1439-0396.2010 .00991.x.

Pritchett, L. C., C. C. Gay, T. E. Besser, and D. D. Hancock. 1991. Management and production factors influencing immunoglobulin $\mathrm{G}_{1}$ concentration in colostrum from Holstein cows. J. Dairy Sci. 74:2336-2341. https://doi.org/10.3168/jds.S0022-0302(91)78406 -3 .

Raboisson, D., P. Trillat, and C. Cahuzac. 2016. Failure of passive immune transfer in calves: A meta-analysis on the consequences and assessment of the economic impact. PLoS One 11:e0150452. https: //doi.org/10.1371/journal.pone.0150452.

Rastani, R. R., R. R. Grummer, S. J. Bertics, A. Gümen, M. C. Wiltbank, D. G. Mashek, and M. C. Schwab. 2005. Reducing dry pe- riod length to simplify feeding transition cows: Milk production, energy balance, and metabolic profiles. J. Dairy Sci. 88:1004-1014. https://doi.org/10.3168/jds.S0022-0302(05)72768-5.

Santos, J. E. P., I. J. Lean, H. Golder, and E. Block. 2019. Meta-analysis of the effects of prepartum dietary cation-anion difference on performance and health of dairy cows. J. Dairy Sci. 102:2134-2154. https://doi.org/10.3168/jds.2018-14628.

Schuenemann, G. M., I. Nieto, S. Bas, K. N. Galvão, and J. Workman. 2011. Assessment of calving progress and reference times for obstetric intervention during dystocia in Holstein dairy cows. J. Dairy Sci. 94:5494-5501. https://doi.org/10.3168/jds.2011-4436.

Soberon, F., E. Raffrenato, R. W. Everett, and M. E. van Amburgh. 2012. Preweaning milk replacer intake and effects on long-term productivity of dairy calves. J. Dairy Sci. 95:783-793. https://doi .org/10.3168/jds.2011-4391.

Soufleri, A., G. Banos, N. Panousis, D. Fletouris, G. Arsenos, and G. E. Valergakis. 2019. Genetic parameters of colostrum traits in Holstein dairy cows. J. Dairy Sci. 102:11225-11232. https://doi.org/ $10.3168 /$ jds.2019-17054.

Sutter, F., S. Borchardt, G. M. Schuenemann, E. Rauch, M. Erhard, and W. Heuwieser. 2019. Evaluation of 2 different treatment procedures after calving to improve harvesting of high-quantity and high-quality colostrum. J. Dairy Sci. 102:9370-9381. https://doi .org/10.3168/jds.2019-16524.

USDA. 2007. Dairy 2007: Heifer Calf Health and Management Practices on U.S. Dairy Operations. APHIS.

Van Saun, R. J., and C. J. Sniffen. 2014. Transition cow nutrition and feeding management for disease prevention. Vet. Clin. North Am. Food Anim. Pract. 30:689-719. https://doi.org/10.1016/j.cvfa 2014.07.009.

Van Saun, R. J., and C. J. Sniffen. 2016. Protein and amino acid requirements of the close-up dry cow. WCDS Advances in Dairy Technology 28:301-312.

Vandeputte, S., J. Detilleux, and F. Rollin. 2014. Investigation of colostrum quality in beef cattle by radial immunodiffusion and brix refractometry. Vet. Rec. 175:353. https://doi.org/10.1136/vr .101590 .

Vieira-Neto, A., G. A. Duarte, R. Zimpel, W. W. Thatcher, and J. E. P. Santos. 2021. Days in the prepartum group are associated with subsequent performance in Holstein cows. J. Dairy Sci. 104:59645978. https://doi.org/10.3168/jds.2020-18889.

Watters, R. D., J. N. Guenther, A. E. Brickner, R. R. Rastani, P. M. Crump, P. W. Clark, and R. R. Grummer. 2008. Effects of dry period length on milk production and health of dairy cattle. J. Dairy Sci. 91:2595-2603. https://doi.org/10.3168/jds.2007-0615.

Weich, W., E. Block, and N. B. Litherland. 2013. Extended negative dietary cation-anion difference feeding does not negatively affect postpartum performance of multiparous dairy cows. J. Dairy Sci. 96:5780-5792. https://doi.org/10.3168/jds.2012-6479.

Zentrich, E., M. Iwersen, M.-C. Wiedrich, M. Drillich, and D. KleinJöbstl. 2019. Short communication: Effect of barn climate and management-related factors on bovine colostrum quality. J. Dairy Sci. 102:7453-7458. https://doi.org/10.3168/jds.2018-15645.

\section{ORCIDS}

S. Borchardt @ https://orcid.org/0000-0003-3937-5777

F. Sutter ๑ https://orcid.org/0000-0002-0674-3994

W. Heuwieser () https://orcid.org/0000-0003-1434-7083

P. Venjakob @ https://orcid.org/0000-0001-7541-5508 